\title{
Extracellular Vesicles as Natural Nanosized Delivery Systems for Small-Molecule Drugs and Genetic Material: Steps towards the Future Nanomedicines
}

\author{
Mustafa Kotmakçı*a, Vildan B. Çetintaş ${ }^{\mathrm{b}}$ \\ a Department of Pharmaceutical Biotechnology, Faculty of Pharmacy, Ege University, Bornova, Izmir, Turkey. b \\ Department of Medical Biology, Faculty of Medicine, Ege University, Bornova, Izmir, Turkey
}

Received, July 22, 2015; Revised, August 13, 2015; Accepted, August 23, 2015; Published, September 5, 2015.

\begin{abstract}
A new platform for drug, gene and peptide-protein delivery is emerging, under the common name of "extracellular vesicles". Extracellular vesicles (EVs) are 30-1000 nm-sized cell-derived, liposomelike vesicles. Current research on EVs as nano-delivery systems for small-molecule drugs and genetic material, reveal that these tiny, biologically-derived vesicles carry a great potential to boost the efficacy of many therapeutic protocols. Several features of EVs; from efficacy to safety, from passive to active targeting ability, the opportunity to be biologically or chemically labelled, and most importantly, their eobiotic origin make them promising candidate for development of the next generation personalized nanomedicines. The aim of this article is to provide a view on the current research in which EVs are used as drug/genetic material delivery systems. Their application areas, drug loading and targeting strategies, and biodistribution properties are discussed.
\end{abstract}

This article is open to POST-PUBLICATION REVIEW. Registered readers (see "For Readers") may comment by clicking on ABSTRACT on the issue's contents page.

\section{INTRODUCTION}

Each active pharmaceutical ingredient undergoes a formulation step before administration to the patients. Formulation of drug delivery systems using proper excipients helps to improve their therapeutic activity and reduces side effects (1). The ultimate goal of the formulation and drug delivery studies is to help patients by designing clinically relevant, effective and safe formulations. Advancements in drug delivery technologies have led to development of various clinically acceptable formulations with improved patient compliance and ease of administration (2).

Among them, nanoparticle-based systems represent one of the most promising innovations in the field of drug delivery. These systems include polymeric nanoparticles, dendrimers, nanocapsules, liposomes, solid lipid-based nanoparticles, protein conjugates, micro- and nanoemulsions, inorganic nanoparticles, carbon nanotubes etc (3). They have been studied for the development of formulations with increased drug solubility (4-7), improved bioavailability (7-12), modified biodistribution parameters $(10,11,13)$, improved drug activity (14-16), reduced drug toxicity $(12,15,17)$, reduced dosing regimen (18), and for drug targeting $(15,16,19)$. Furthermore, these systems are essential tools for enabling systemic delivery of otherwise unstable nucleic acid therapeutics (20-24), peptides and protein drugs (19,25-27).

Difficulties with currently available
nanoparticle delivery systems Although appreciable improvement has been achieved in designing advanced drug delivery systems, there are still issues in which significant effort should be made to cover the ground of a clinically adequate therapeutic delivery system. Despite their versatility and enormous potential in therapeutics delivery applications, conventional nanoparticles have a considerable drawback; their xenobiotic origin, which means that they are composed of constituents that are alien to the organism to which they will be administered. Materials of xenobiotic origin often lead to unwanted immune reactions, and unexpected toxicity (28). So their safety is the subject of substantial criticism (29-34). From regulatory point of view the exposure safety of nanoparticles has long being considered limited as there are still insufficient data related to the acute and chronic toxic effects of nanoparticles upon administration to humans (35-38).

\footnotetext{
Corresponding Author: Dr. Mustafa Kotmakçı, Ege University, Faculty of Pharmacy, Department of Pharmaceutical Biotechnology, Ankara Street No: 172/98, 35100 Campus-Bornova/Izmir, Turkey; E-mail: mustafa.kotmakci@ege.edu.tr; mustkot@gmail.com
} 
Predominant part of studies dealing with development and application of nanoparticles for therapeutics delivery are of in vitro testing, or in vivo animal experiment character. Wherever in vitro data can be contradictory with the results obtained in vivo (39), it is the same when in vivo animal data are to be extrapolated to clinical trials (40). Thus, the toxicity of drug nanocarriers and the difficulty to reliably prove their safety are the main impediments for the development of an efficacious and clinically safe nanosized delivery system (41).

\section{Extracellular vesicles: short description}

Because of the obstacles with the currently available nanoparticle drug delivery systems, researchers continuously seek for innovative nanosized materials with biological origin. A group of biological nanosized vesicles, produced during natural processes of cell cycle are getting increasingly attractive for this purpose. These cell-derived endogenous vesicles are known as extracellular vesicles (EVs). EVs are small, lipid bilayer-enclosed vesicles which are released from the cells. They are logistic systems of the cells that carry proteins, lipids, mRNA, microRNAs, and DNA. The term "extracellular vesicle", indeed, is a general term for all secreted vesicles, and based on their biogenesis they are classified into; exosomes, microvesicles (MVs) and apoptotic blebs (42).

Exosomes are first reported by Johnstone and co-workers as vesicles secreted from reticulocytes (43). Exosomes are small membrane-bound vesicles that are formed inside endosomes during endosomal maturation and recycling (44). Their size varies between $40-100 \mathrm{~nm}$. Microvesicles or ectosomes are directly formed by budding of the plasma membrane, and their size varies in a much wider range as compared to exosomes (50-1000 $\mathrm{nm})(45,46)$. Apoptotic blebs are formed during late stages of the programmed cell death $(47,48)$. Table 1 shows the main characteristics of different EV types (49). EVs have crucial roles in both normal physiological and pathological processes such as angiogenesis (50), inflammation (51), immune response (52), cell survival (53), autophagy (54), cardiovascular diseases (55), drug resistance (56), and cancer (57).

\section{Biogenesis of exosomes}

In cells, during the endosomal maturation three distinct types of cellular vesicles are formed; early endosomes, late endosomes and recycling endosomes. Early endosomes accept incoming cargo internalized from the plasma membrane and sort it to different intracellular destinations (58). Early endosomes mature into late endosomes. During this maturation, contents fated to be degraded or exported out of the cell are enriched in vesicles that bud inward to the lumen of late endosomes. Late endosomes contain Intraluminal Vesicles (ILVs). This form of the late endosomes is known as Multivesicular Bodies (MVBs). MVBs are either targeted to fuse with lysosomes for destruction of the cargo, or fuse with plasma membrane to secrete the ILVs to the extracellular space in form of exosomes. A superfamily of membrane proteins known as Tetraspanins and endosomal sorting complexes are required for the formation of ILVs. Tetraspanins CD9, CD63, CD37, CD81, or CD82 are specially enriched in the membrane of exosomes and they are often used as exosome biomarkers (59).

Several complex proteins are involved in the formation of ILVs. These are named endosomal sorting complex required for transport (ESCRT). These complexes work together with associated proteins like VPS4, VTA1, and ALIX (60). Interactions of ESCRT complexes and associated proteins with phosphatidylinositol 3-phosphate and ubiquitin leads to inward budding of the endosomal membrane and cargo sorting into the ILVs (61-63).

\section{Biogenesis of Microvesicles}

MVs, also known as ectosomes or microparticles, are formed directly by budding of the plasma membrane. Compared to exosomes, MVs are larger $(50-1000 \mathrm{~nm})$ and more heterogeneous in morphology. Activation of MVs is different from one cell to another. For instance; endothelial and circulating blood cells release MVs when exposed to complement attack, monocyte budding is induced by bacterial cell wall components, platelets release MVs by activation through thrombin, fibroblasts release MVs in response to stress relaxation (64).

Table 1. Properties of different extracellular vesicle types (49)

\begin{tabular}{llll}
\hline EV type & Shape & Reported size range (nm) & Origin \\
\hline Exosomes & cup shaped-to-spherical & $\sim 30-100$ & Multi vesicular bodies \\
Microvesicles & spherical-to-irregular & $\sim 200-500$ & Plasma membrane \\
Apoptotic blebs & irregular & $\sim 1250-2500$ & Entire membranous cell components \\
\hline
\end{tabular}


Specific lipid composition of the vesicle membrane and cell cytoskeleton provides the formation of microvesicles (65). Aminophospholipids; phosphatidylserine and phosphatidylethanolamine are segregated in the inner leaflet, whereas phosphatidylcholine and sphingomyelin are enriched in the external leaflet. Flippase and floppase enzymes transfer phospholipids between the inner and outer leaflets (48). Reverse sided translocation of the phosphatidylserine induces the membrane budding and microvesicle formation. The formation of exosomes, MVs and apoptotic blebs is schematized in Figure 1.

\section{EVS AS EMERGING DRUG DELIVERY NANOVESICLES}

The structural feature that makes EVs especially attractive for drug delivery purpose is their analogy to liposomes. As liposomes are composed of phospholipids, they mimic the properties of cell membranes. As such, they are currently widely used in studies for delivering active pharmaceutical ingredients and several liposomebased products have taken their place in the market (67). Know-how established in the field of liposome research provides some fundamental knowledge about the properties of EVs like physicochemical characteristics, drug loading, drug release, targeting and stability $(44,68-75)$. In addition to their structural similarity to liposomes, the mode of production of EVs is another feature which makes them more advantageous. They are produced by the cells themselves, which means that they are composed of the cell membrane lipids and proteins. This allows them to mimic the cell membrane in an extent even greater than liposomes. This means when EVs originating from a living organism's own cells are administered to the same organism in vivo, possess the ability to deliver molecules even through hard-to-cross barriers like blood-brain barrier (76).

\section{EVs in small molecule drug delivery}

EVs should be effectively loaded with drug molecules in order to be used as drug delivery systems. Several strategies are described for small molecule and genetic material loading to their synthetic counterparts; liposomes (75,77-82). However, most of these strategies are not feasible for drug loading into exosomes, as they require modification of the vesicle inner content, inclusion of cationic lipids, or pre-dissolving lipids in an organic solvent (75).

Two major strategies have been suggested for loading EVs with small molecule drugs. These strategies are: 1) loading after EV isolation and 2) loading during EV biogenesis (83). Table 2 summarizes the studies collected for small molecule drug delivery with EVs and the methods employed for drug loading.

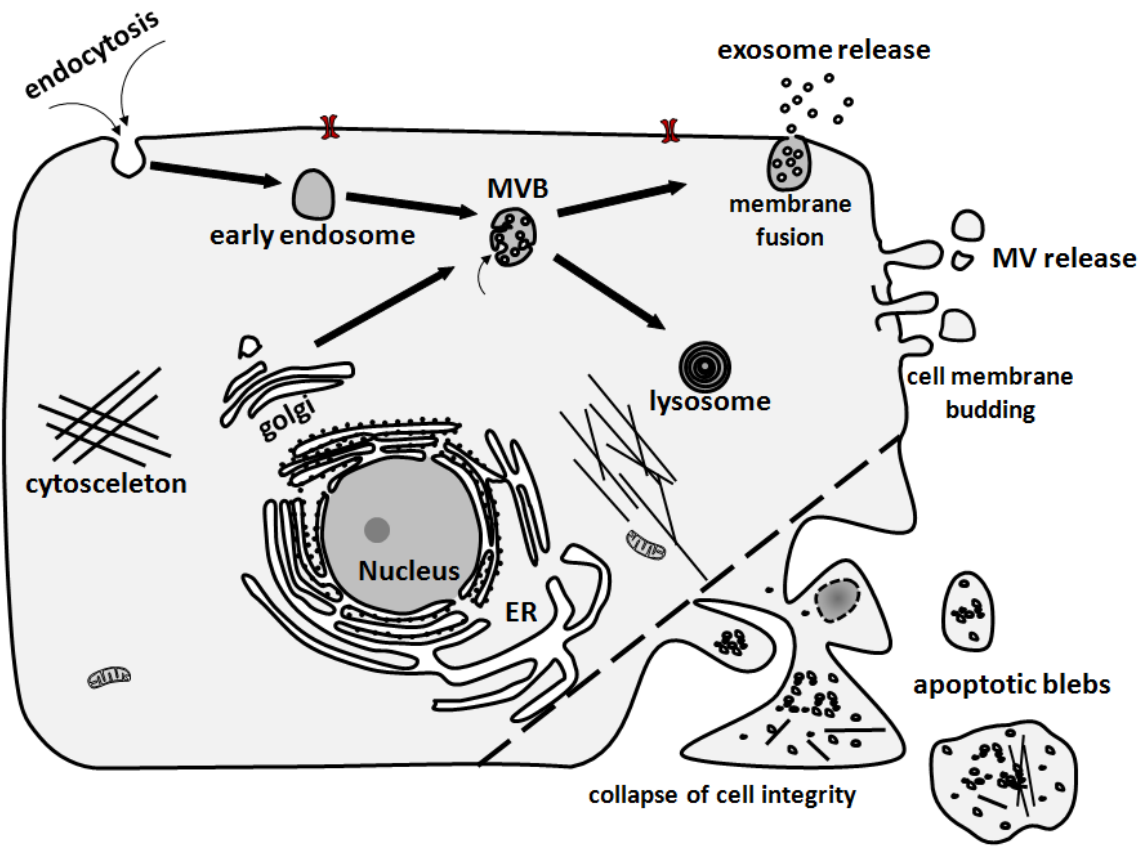

Figure 1. Illustration of extracellular vesicle release from cells. Exosomes are formed inside multivesicular bodies by inward budding of the endosomal membrane. MVs are directly shed from the cell membrane by outward budding. Apoptotic blebs are formed during the collapse of the cell integrity as a result of the late processes of apoptotic cell death. Abbreviations: MVB - multivesicular body; MV- microvesicles; ER- endoplasmic reticulum. Adapted with permission from J Cell Biol 2013; 200(4): 373-83 C2013 The Rockefeller University Press (66) 
Table 2. Studies on the small molecule drug delivery using EVs

\begin{tabular}{|c|c|c|c|}
\hline Vesicle type & Drug & Loading method & Key findings \\
\hline Exosomes & curcumin & $\begin{array}{l}\text { Incubation at } \mathrm{RT} \\
\text { for } 5 \mathrm{~min}\end{array}$ & $\begin{array}{l}\text { Increased solubility and stability in vitro. Increased } \\
\text { bioavailability and enhanced anti-inflammatory effect in } \\
\text { vivo (84). }\end{array}$ \\
\hline Exosomes & $\begin{array}{l}\text { cucurbitacin-I } \\
\text { and curcumin }\end{array}$ & $\begin{array}{l}\text { Incubation at RT } \\
\text { for } 5 \mathrm{~min}\end{array}$ & $\begin{array}{l}\text { Effective uptake by microglia cells after intranasal } \\
\text { administration, and enhanced anti-inflammatory and } \\
\text { anticancer effect in vivo (85). }\end{array}$ \\
\hline Exosomes & doxorubicin & $\begin{array}{l}\text { Incubation at } 37^{\circ} \mathrm{C} \\
\text { for } 2 \mathrm{~h}\end{array}$ & $\begin{array}{l}\text { Enhanced in vitro and in vivo antitumor efficiency is } \\
\text { reported as compared to free doxorubicin. No toxicity } \\
\text { assessment for exosomes is reported (86). }\end{array}$ \\
\hline Exosomes & doxorubicin & Electroporation & $\begin{array}{l}\text { Exosomes with targeting moiety delivered doxorubicin } \\
\text { directly to tumor tissue and inhibited tumor growth in vitro } \\
\text { (87). }\end{array}$ \\
\hline Exosomes & doxorubicin & $\begin{array}{l}\text { Incubation at } 37^{\circ} \mathrm{C} \\
\text { for } 2 \mathrm{~h}\end{array}$ & $\begin{array}{l}\text { Intra tumoral injection revealed greater impact on tumor } \\
\text { size reduction as compared to liposomal doxorubicin. } \\
\text { Intravenous injection caused asphyxiation, a condition with } \\
\text { heavy breathing, and clearance by innate immune system is } \\
\text { reported (88). }\end{array}$ \\
\hline Exosomes & $\begin{array}{l}\text { doxorubicin, } \\
\text { paclitaxel }\end{array}$ & $\begin{array}{l}\text { Incubation at } 37^{\circ} \mathrm{C} \\
\text { for } 2 \mathrm{~h}\end{array}$ & $\begin{array}{l}\text { Enhanced in vitro cytotoxicity of both drugs is observed. } \\
\text { Exosomal doxorubicin and paclitaxel crossed the blood- } \\
\text { brain barrier (BBB) in vivo in Danio Rerio embryo model, } \\
\text { while drugs alone did not (89). }\end{array}$ \\
\hline $\begin{array}{l}\text { Exosome- } \\
\text { mimetic } \\
\text { nanovesicles }\end{array}$ & $\begin{array}{l}\text { doxorubicin, } \\
\text { gemcitabine, } \\
\text { 5-fluorouracil, } \\
\text { carboplatin }\end{array}$ & $\begin{array}{l}\text { Serial extrusion of } \\
\text { drug-treated cells } \\
\text { through filters or } \\
\text { membranes }\end{array}$ & $\begin{array}{l}\text { Researchers found higher encapsulation and production } \\
\text { efficiency for drug loaded exosome-mimetic nanovesicles } \\
\text { (86). }\end{array}$ \\
\hline
\end{tabular}

Small molecule drug loading after EV isolation

Small molecule drug loading after EV isolation may be achieved by simple incubation of the drug of interest with isolated exosomes. This allows loading of lipophilic molecules in the lipid bilayer of the EVs. Examples for drugs loaded by incubation are curcumin $(84,85)$, cucurbitacin-I (85), doxorubicin (88,89), paclitaxel (89). After intranasal administration exosomal JSI124 and exosomal curcumin have efficiently taken up by microglia cells, while the unencapsulated compounds have failed to cross the blood brain barrier and did not show any therapeutic effect (85). Doxorubicin has been loaded into unmodified exosomes isolated from 4T1, MCF-7 and $\mathrm{PC} 3$ cell lines through incubation at $37^{\circ} \mathrm{C}$ for $2 \mathrm{~h}$. Exosomal doxorubicin was reported to inhibit tumor growth with a significantly higher extent than liposomal doxorubicin in this study (88). Yang et al. loaded doxorubicin and paclitaxel to exosomes from U-87MG cells and bEND.3 cells (89). Enhanced in vitro cytotoxicity of both drugs is observed in the exosomal form. The enhancement seems to be dependent on the exosome donor cells. Brain uptake of exosomal doxorubicin and paclitaxel is observed, while drugs alone did not cross the blood-brain barrier (BBB) in vivo in a zebra fish embryo model. In vivo experiments revealed that crossing through
BBB also depends on the exosome donor cells (89).

Another more invasive strategy to load active compounds to isolated exosomes is applying electroporation (87). This process is somehow harmful for the exosomal membrane and requires additional incubation period at $37^{\circ} \mathrm{C}$ after the electroporation process in order to ensure that the membrane is recovered. Researchers explore the possibilities to minimize the risk of vesicle disruption and particle size enlargement. The method of trehalose pulse media to produce exosomes loaded with super paramagnetic iron oxide seems promising in that respect (90). For the future it seems beneficial for improvement of the efficiency of electroporation method for exosome drug loading. Unsuccessful attempts to load small molecule drugs to exosomes by electroporation are also reported (88). Apart from these methods recently freeze-thaw cycles (91), ultrasonication, saponin mediated loading, extrusion (91,92), and hypotonic dialysis (92) were used for loading biological molecules into EVs. Application of these methods to small molecule drugs can be considered promising strategies as well. 
Small molecule drug loading during EV biogenesis

Small molecule drug loading during EV biogenesis has not been directly addressed to date. It is most likely that this occurs based on the natural mechanisms of cells to excrete xenobiotic or cytotoxic molecules out of the cell via EVs. In an early research, not concerned with the drug delivery potential of EVs, it was reported that increased lysosomal accumulation of cisplatin occurs when the drug is administered to resistant cancer cells (93). In addition to the increased lysosomal accumulation, researchers also reported that lysosomal compartment is markedly reduced, and that cisplatin resistant cells release exosomes with 2.6 fold higher cisplatin content than sensitive cells. Another cytotoxic drug; daunorubicin has also been shown to accumulate in the lysosomes in anthracyclin-resistant cells, but the potential of excretion through exosomes was not investigated $(94,95)$. A study by Yamagishi and co-workers suggests that $\mathrm{p}$ glycoprotein, an important member of the cell membrane proteins which is responsible of the efflux pump-type drug resistance, may be involved in this phenomenon (96). They concluded that chemoresistance in multidrug resistant cells involves accumulation of doxorubicin in the lysosomes. It implies that multivesicular bodies carry cell membrane proteins of efflux pump family associated to their membrane. Given the fact that ILVs are already formed in the endosomes, they have enough incubation time with the "excreted" drug in the lysosomal lumen, and become drug-loaded until being released out of the cell (Figure 2). Recently this was demonstrated with paclitaxel, which is another p-glycoprotein substrate. Researchers incubated bone marrow mesenchymal stromal cells (SR4987), which express high levels of pglycoprotein, in a medium containing paclitaxel and subsequently isolated exosomes from the culture supernatant. It was shown that this chemotherapeutic agent was incorporated into exosomes during their biogenesis (97). However, it was not clarified whether exosomes have become drug-loaded in the cells, or later in the growth medium, after being released.

Another strategy for drug loading before exosome isolation is incubation of selected cells with chemotherapeutic drugs and then performing serial extrusion of these cells through membranes with consecutively narrowing pore sizes. By this means exosome-mimetic nanovesicles are produced. Examples of drugs loaded to exosomemimetic nanovesicles include doxorubicin, gemcitabine, 5-fluorouracil or carboplatin (86). These exosome-mimetic nanovesicles showed concentration depended drug loading efficiency, good in vitro cell inhibitory activity and good in vitro and in vivo targeting ability.

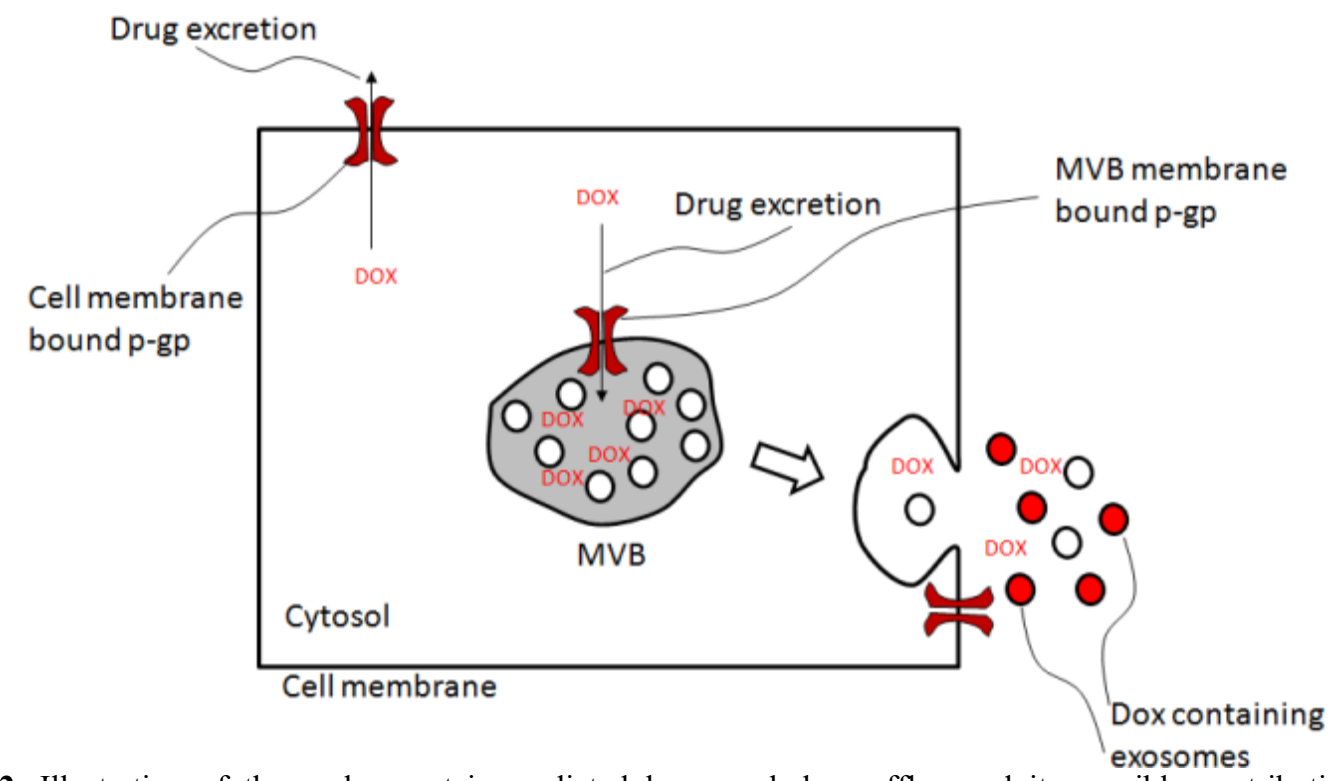

Figure 2. Illustration of the p-glycoprotein mediated lysosomal drug efflux and its possible contribution to the production of drug-loaded exosomes during their biogenesis. P-glycoprotein associated to the endosomal membrane excretes the internalized drug into the endosomal lumen. Here, newly formed exosomes are literally incubated with the drug and become "drug-loaded" before being released from the cell. Abbreviations are: MVB; multivesicular body, DOX; doxorubicin, p-gp; p-glycoprotein. Adapted with permission from J Biol Chem 2013; 288(44): 31761-31771. C2013 The American Society for Biochemistry and Molecular Biology (96) 


\section{EVs in genetic material delivery}

It is widely recognized that free genetic material (DNA, RNA) is rapidly cleared from the circulation via degradation by nucleases or filtration by the kidneys and cannot accumulate in the tissues or cells of interest. Additionally, NAs are unable to pass cellular membranes because of their electrical charge which is similar to outer cell membrane charge that prevents them from crossing the membrane (98-100). For this reason NAs intended for therapeutic application should be suitably formulated.

Recent evidence has shown that different kinds of RNA are being transported by exosomes or microvesicles as a normal route of cell-cell communication. These RNA molecules are called exosomal shuttle RNA (esRNA) which have important roles in cell-cell signaling between a variety of cell types and contribute to cancer progression and metastasis (101-105). RNA sequencing has shown that MicroRNAs (miRNAs), that are post-transcriptional modulators of gene expression are enriched in the multivesicular bodies in form of miRNA-RISC complexes and released in exosomes (106). When taken up by recipient cells, these complexes serve as ready-to-use components of posttranslational gene silencing machinery and represent an attractive alternative approach for therapeutic miRNA delivery. Therefore, the majority of the research on delivery of therapeutics by EVs is based on employing their natural feature of genetic material transfer during cell-cell communication.

During natural communication or cell functioning the genetic material to be delivered is synthesized and loaded to EVs naturally in the cells (107). Apart from this, there are several experimental methods for loading genetic material to EVs for therapeutic purpose (74). These include electroporation $(108,109)$, chemical transfection (110), transfection/transduction of EV producer cells $(111,112)$, and activation of cells with outer signals (113). Among these methods, transfection of $\mathrm{EV}$ producing cells seems the most effective way of introducing desired genes to EVs. In this method, once a desired gene is introduced to the cells they can provide a continuous overexpression of the transgene and constantly produce EVs containing the gene of interest.

As is the case with small molecule drug loading, the specific mechanism of NA enrichment into EVs during their biogenesis is not fully understood. Yet, some recent research papers give clues about how specific RNA molecules are overly sorted into EVs. In some studies it has been shown that cells transfected with a vector for overexpression of a specific miRNA, release EVs with increased level of this miRNA $(104,111)$. Enrichment of miRNAs in EVs and their transfer to acceptor cells has been shown to be modulated by endogenous mRNA levels. When the expression of endogenous mRNAs that are target for miRNAs in the cells is downregulated, these miRNAs are enriched in exosomes, and vice versa (111). Fusing zipcodelike sequences to the desired genes can enhance the loading specificity of specific NAs (114).

Attempts to investigate the EVs for therapeutic genetic material delivery considerably increased after the pioneering works of groups interested in development of EV systems for siRNA/miRNA delivery $(76,115)$. Alvarez-Erviti and co-workers tested the potential of exosomes from self-derived dendritic cells to deliver siRNA to the mouse brain after systemic injection (76). Authors isolated dendritic cells from mice and transfected them with a plasmid encoding an exosomal membrane protein genetically fused to a targeting ligand. In this way authors aimed to produce exosomes with specific brain-targeting property. Isolated exosomes have been loaded with GAPDH siRNA by electroporation and were administered to mice. As the result, specific GAPDH mRNA suppression in different brain parts, such as striatum, midbrain and the cortex has been observed (76).

Bolukbasi and co-workers have demonstrated that specific sequences can help to enrich mRNA's into vesicles (114). They concluded that such sequences may help to develop cell lines that produce vesicles, loaded with specific mRNAs, shRNAs or non-coding regulatory RNAs of therapeutic value.

A group of researchers attempted to use bacterial outer membrane vesicles (OMV) for siRNA delivery (119). For this purpose they employed a mutant $E$. coli strain that exhibits reduced endotoxicity towards human cells. They loaded the OMVs by electroporation and observed that this process did not affect the properties of OMVs. These OMVs internalized to SCOV3 cells and the carried siRNA escaped from lysosomes, a process which is very important in order to transfection to take place. High gene silencing and anticancer effect are observed in vitro. Also, high antitumor efficacy is observed in vivo in comparison to free siRNA as demonstrated by tumor xenograft growth regression. 
Table 3. Recent examples of EVs used for genetic material delivery

\begin{tabular}{|c|c|c|c|c|}
\hline Type of EVs a & $\begin{array}{l}\text { Control } \\
\text { carrier }^{\text {b }}\end{array}$ & NA & $\begin{array}{l}\text { Loading } \\
\operatorname{method}^{\mathrm{c}}\end{array}$ & Key findings \\
\hline MVs & ND & miRNA & $\begin{array}{l}\text { During } \\
\text { biogenesis in } \\
\text { transfected cells }\end{array}$ & $\begin{array}{l}\text { Demonstration of secretion of transfected miRNAs in vitro } \\
\text { and in vivo. In vivo delivery of desired miRNA is achieved } \\
\text { by injection of ex vivo transfected self-macrophages to } \\
\text { tumor- bearing mice (115). }\end{array}$ \\
\hline Exosomes & $\begin{array}{l}\text { Lipofectamine } \\
2000\end{array}$ & siRNA & Electroporation & $\begin{array}{l}\text { Cell type-specific in vitro gene knockdown comparable to } \\
\text { control carrier. Specific knockdown of selected genes has } \\
\text { been achieved in targeted brain tissue in vivo. Implication } \\
\text { for in vivo toxicological and immunological tolerability of } \\
\text { exosomes through in vitro tests ( } 76 \text { ). }\end{array}$ \\
\hline MVs/exosomes & $\begin{array}{l}\text { Conventionally } \\
\text { isolated AAVs }\end{array}$ & $\mathrm{AAV}^{\mathrm{d}}$ & $\begin{array}{l}\text { During } \\
\text { biogenesis in } \\
\text { transfected cells }\end{array}$ & $\begin{array}{l}\text { Demonstrated for the first time that AAV is incorporated in } \\
\text { or associated to EVs. } \\
\text { AAV containing EVs exhibit enhanced gene transfer as } \\
\text { compared to conventionally isolated AAVs (112). }\end{array}$ \\
\hline Exosomes & ND & $\begin{array}{l}\text { anti- } \\
\text { miRNA }\end{array}$ & $\begin{array}{l}\text { During } \\
\text { biogenesis in } \\
\text { transfected cells }\end{array}$ & $\begin{array}{l}\text { Contact independent transfer of anti-miR-9 from } \\
\text { transfected mesenchymal stem cells to glyoblastoma } \\
\text { multiforme (GBM) cells in vitro. Decreased level of P-gb } \\
\text { and enhanced sensitivity of GBM to temozolomide is } \\
\text { observed (116). }\end{array}$ \\
\hline Exosomes & $\begin{array}{l}\text { "self-delivering } \\
\text { siRNA"(sdRNA) } \\
\text { and } \\
\text { Lipofectamine } \\
2000\end{array}$ & siRNA & $\begin{array}{l}\text { Lipofectamine, } \\
\text { electroporation }\end{array}$ & $\begin{array}{l}\text { Chemical loading provides higher silencing efficiency. } \\
\text { Higher silencing effect with exosomes as compared to } \\
\text { Lipofectamine control group (110). }\end{array}$ \\
\hline Exosomes & ND & $\begin{array}{l}\text { siRNA } \\
\text { miRNA }\end{array}$ & $\begin{array}{l}\text { During } \\
\text { biogenesis in } \\
\text { transfected cells }\end{array}$ & $\begin{array}{l}\text { The encapsulated siRNA loaded to targeted EVs } \\
\text { significantly inhibited expression of the target gene in vitro. } \\
\text { Significantly high targeting and inhibition of tumor growth } \\
\text { are achieved in vivo in tumor xenografted mice with } \\
\text { miRNA loaded EVs (117). }\end{array}$ \\
\hline Exosomes & Oligofectamine & siRNA & Electroporation & $\begin{array}{l}\text { Higher gene silencing efficiency as compared to free and } \\
\text { scrambled siRNA, comparable results with oligofectamine } \\
(109) \text {. }\end{array}$ \\
\hline MVs & ND & siRNA & $\begin{array}{l}\text { during } \\
\text { biogenesis in } \\
\text { transfected cells }\end{array}$ & $\begin{array}{l}\text { Demonstrated the antitumor effect of microvesicle } \\
\text { delivered anti-TGF- } \beta 1 \text { siRNA in vitro and in vivo (118). }\end{array}$ \\
\hline Exosomes & $\begin{array}{l}\text { HiPerFect, } \\
\text { FuGENE }{ }^{\circledR} \text { HD }\end{array}$ & $\begin{array}{l}\text { miRNA } \\
\text { mimic or } \\
\text { miRNA } \\
\text { inhibitor }\end{array}$ & Electroporation & $\begin{array}{l}\text { Exosomes provided higher miRNA inhibition and } \\
\text { subsequently higher TNF- } \alpha \text { level reduction as compared to } \\
\text { commercially available transfection reagents. Significantly } \\
\text { lower cytotoxicity in vitro as compared to commercial } \\
\text { reagents. Efficient miR-155 mimic delivery to the liver in } \\
\text { vivo (108). }\end{array}$ \\
\hline OMVs ${ }^{\mathrm{e}}$ & ND & siRNA & Electroporation & $\begin{array}{l}\text { Electroporation did not affect the properties of OMVs. High } \\
\text { gene silencing and anticancer effect in vitro and in vivo. } \\
\text { Even higher effect with targeted OMVs in vivo. No } \\
\text { evidence for non-specific in vivo side effects were reported } \\
\text { (119). }\end{array}$ \\
\hline
\end{tabular}

${ }^{\mathbf{a}}$ as indicated by the authors, ${ }^{\mathbf{b}}$ commercially available or conventionally used carrier system, ${ }^{\mathbf{c}}$ the method used for nucleic acid loading into extracellular vesicles, ${ }^{\mathbf{d}}$ AAV stands for adeno associated virus which contains single stranded $4.7 \mathrm{~kb}$ long DNA (120), ${ }^{\mathrm{e}}$ OMV stands for bacterial outer membrane vesicles. ND - not defined.

The fact that researchers observed no evidence for non-specific in vivo side effects underlines the huge potential of using special bacterial strains as producers of biological membrane vesicles for drug delivery (119). Table 3 summarizes some recent studies conducted for NA delivery via EVs.

When considering a nanoparticulate system for therapeutics delivery, its ability to protect the cargo molecules against a variety of environmental factors is a pivotal feature. These include both biochemical factors (enzymatic degradation by nucleases) and physicochemical factors (oxidation, $\mathrm{pH}$ or temperature changes). Almost any pharmaceutical formulation study is accompanied by stability experiments to prove if the developed formulation will maintain loaded drug molecules or NAs in their native form for a suitably long period of time. Although this is very important from pharmaceutical viewpoint there are still only limited stability studies performed 
with EVs. Example for long-term storage stability of EVs is the work of Ge and co-workers. They showed that plasma-derived EVs stored at $-20^{\circ} \mathrm{C}$ are able to retain their miRNA content unchanged for 5 years (121). Limited number of studies showed that EVs were able to protect internalized RNA molecules from degradation by RNase $(108,122)$. For the future, in addition to comprehensive storage stability experiments, in vitro nuclease treatment and serum stability studies would reveal valuable information about the shelf life, and possible in vivo stability concerns of experimentally designed EV systems for NA delivery.

\section{BIODISTRIBUTION AND TARGETING STUDIES ON EVS}

During development of new delivery systems, the biodistribution after administration to the body is a very important issue that should be investigated, as the site of distribution determines the efficacy and toxicity of drugs. So, in order to avoid side effects many drugs, especially those for cancer treatment, are desired to accumulate only at the diseased site of the body. Providing targeted delivery of drugs to the site of interest not only reduces the side effect but also increases the potency and efficacy of the treatment. Nanoparticulate drug delivery systems provide versatile ways of achieving targeted drug delivery. Owing to their nano-size they offer passive targeting to sites with enhanced capillary permeability. Also, they provide active drug targeting by attaching to their surface, targeting ligands which recognize specific molecules existing on the diseased cells. EVs share these common features of synthetic nanoparticles. Currently the biodistribution of EVs is being investigated with employment of four different strategies. These are 1) using lipophilic fluorescent dyes (see EV-1 in Figure 3) $(84,88,91,123,124), 2)$ using radio conjugate molecules (see EV-2 in Figure 3) $(88,125), 3$ ) applying genetic engineering to label EVs with proteins (see EV-3 and EV-4 in Figure 3) $(124,126,127)$, and 4) modifying the surface of EVs and chemically labeling them by click chemistry (see EV-5 in Figure 3) (128).

Gaussia luciferase fused to an exosomal membrane protein has been used for in vivo visualization and dynamic tracking of exosome biodistribution (126,127). Takahashi et al. suggested that labeling exosomes with a chemiluminescent protein probe could provide a means of in vivo tracking and quantification of exosomal biodistribution (126). For this purpose they constructed a plasmid encoding the fusion protein; gLuc-lactadherin. This fusion protein consists of two domains; one domain is the exosomal outer membrane protein (lactadherin), and the other domain is Gaussia luciferase domain (gLuc). B16-BL6 cells transfected with this plasmid produced exosomes that contain Gaussia luciferase on their surface which provided the in vivo imaging after intravenous administration and Gaussia luciferase substrate (coelenterazine) application. Their results showed that intravenously administered exosomes mainly distributed to liver and lungs of white $\mathrm{BALB} / \mathrm{c}$ mice. 4 hours after the injection the fluorescence remained mainly in lungs and the spleen. They compared chemically labeled exosomes (with PKH26) to gLuc-lactadherin exosomes and observed comparable distribution patterns (126). Lai et al. also developed in vivo tracking method by coupling Gaussia luciferase to the EVs' surface (127). For this purpose they transduced HEK293T cells with viral vectors and used these cells to produce the luciferase conjugated EVs. They administered athymic nude mice intravenously with these exosomes and observed a predominant localization of these EVs in the spleen and liver. Authors noted that EVs coupled to Gaussia luciferase undergo faster elimination as compared to earlier reports with dye-labeled exosomes (see Refs. 8, 13, 14, 17, 22 in Lai et al., 2014). They also applied Gaussia luciferaselabeled exosomes to tumor-xenografted athymic nude mice, and observed that they were rapidly accumulated in subcutaneous tumor xenografts in the first 60 min after injection (127). This finding implied that EVs could be passively targeted to the tumor site by the Enhanced Permeability and Retention effect.

Morishita and coworkers showed once again that the main site for localization of the labeled exogenous exosomes is the mononuclear phagocyte system (liver, lungs and spleen). They provided pharmacokinetic parameters of the radiolabeled exosomes using a twocompartmental model (125). As an alternative strategy to Gaussia luciferase, they engineered cells with streptavidin-lactadherin fusion protein. These exosomes, carrying streptavidin on their surface, were able to bind a radiolabeled biotin complex [ $\left(3-{ }^{125}\right.$ I-iodobenzoyl $)$ norbiotinamide] by simple incubation. This enabled quantitative measurement of the total amount of exosomes accumulated in each organ and improved the in vivo tracking of EVs (125). The radioactivity in the blood of $\mathrm{BALB} / \mathrm{c}$ mice, intravenously administered with these radiolabeled exosomes 
decreased rapidly and distributed to the mononuclear phagocyte system.

\begin{abstract}
isolation and plating of cells from the donor organism (patient)
\end{abstract}

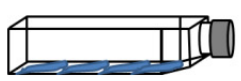

primary cell culture
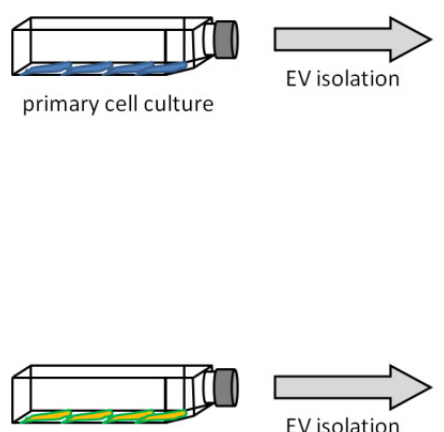

cell culture transfected with streptavidin fusion plasmid

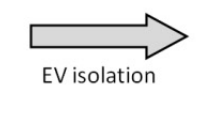

cell culture transfected with luciferase or luciferase + biotin fusion plasmid

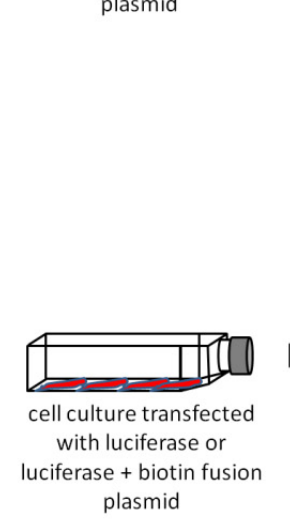

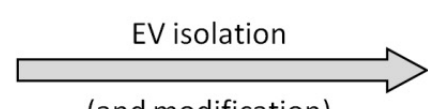

(and modification)

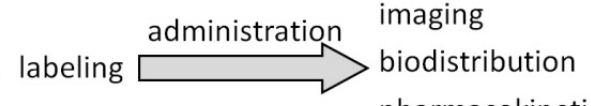

pharmacokinetics
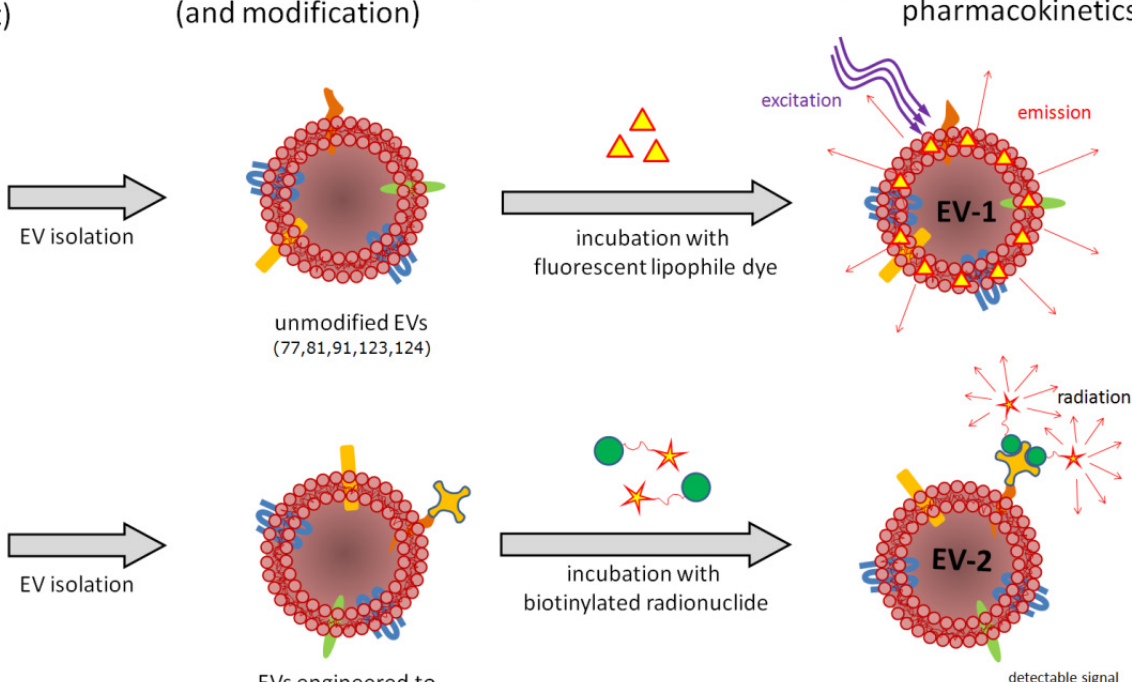

unmodified EVs
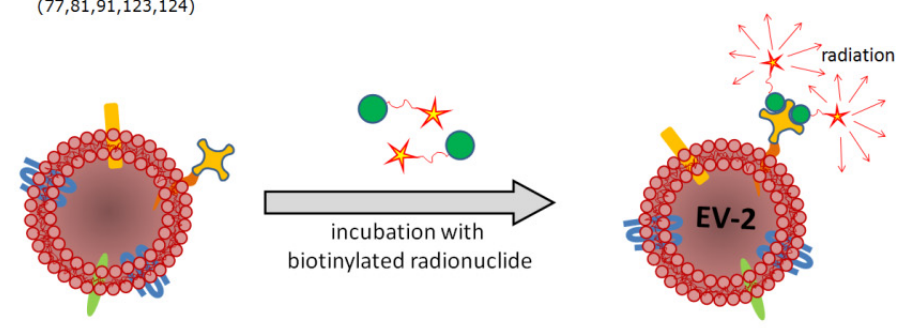
express streptavidin on their surface $(81,125)$
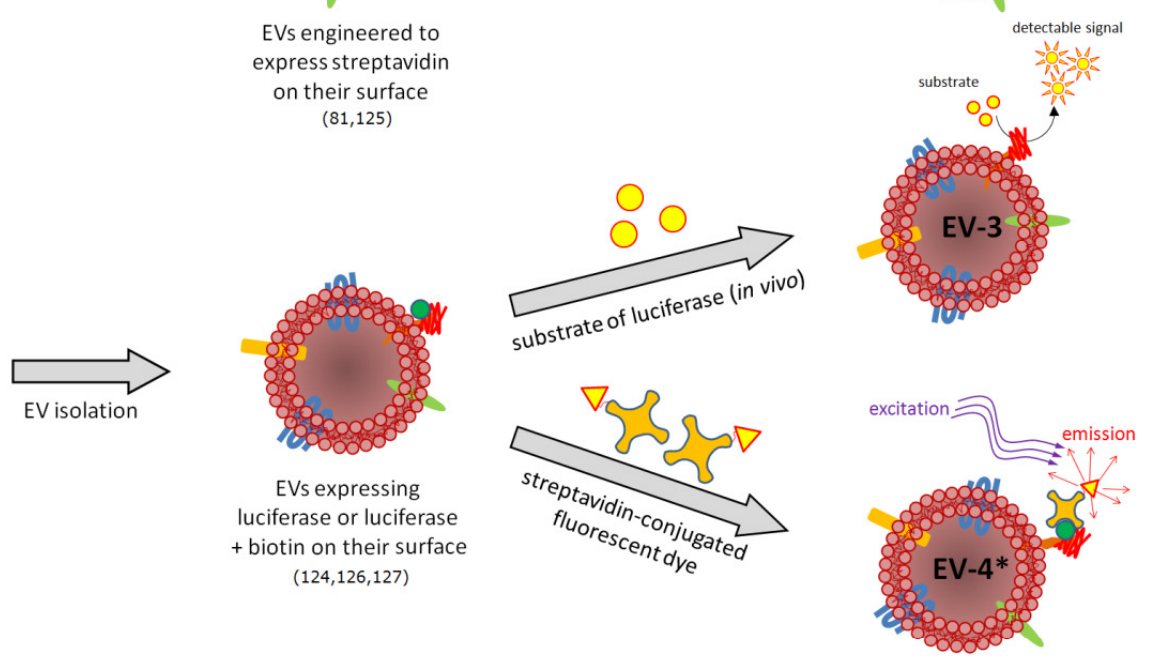

luciferase or luciferas + biotin on their surface $(124,126,127)$
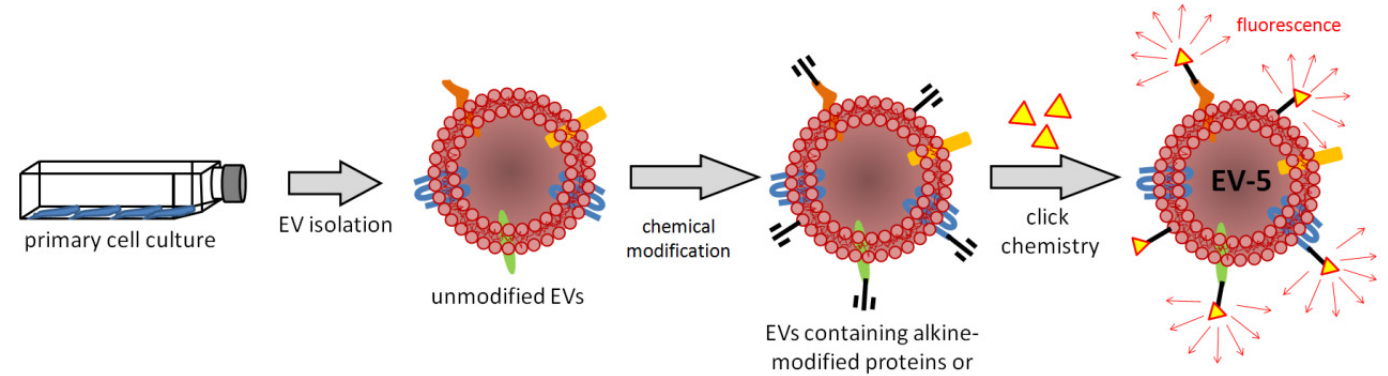

lipids $(128)^{* *}$

\section{Svmbol legend}

$\$ 00$ lipid bilayer of EVs $\quad 700$ protein molecules on EVs' surface

biotin

Naussia luciferase

$\triangle$ fluorescent dye $\star$ radionuclide

luciferase substrate

Figure 3. Representation of different strategies used for extracellular vesicle labeling. * Adapted with permission from ACS Nano 2014; 8(1): 483-494 American Chemical Society (127). ** Adapted with permission from Bioconjug Chem 2014; 25(10): 1777-1784. (O2014 American Chemical Society (128). 
Grange et al. investigated the biodistribution of mesenchymal stem cell-derived, infrared dyelabeled EVs in nude mice with acute kidney injury (123). After intravenous administration of labeled EVs to the mice their distribution was visualized at different time points and researchers reported that EVs accumulated in the region of the injured kidneys, spleen and liver, and the signal retains in this region even after 24 hour. In healthy mice they observed signal only at the left dorsal and central abdominal region and concluded that this corresponded to spleen accumulation. Distribution in liver and spleen has also been shown in ex vivo images (123). They also compared two staining methods for EVs in order to be used for in vivo biodistribution studies; i) preincubated mesenchymal stem cells with the near infrared dyes DiD or DiI and after that isolated exosomes, or ii) initially isolated exsosomes from the cells and then incubated them with dyes. The second method provided better imaging and produced highest signal in injured kidneys.

Smyth et al. investigated the ability to functionalize the surface of exosomes by "click chemistry" (128). They firstly modified exosomal outer membrane proteins or lipids with alkine groups. After stepwise addition of a copper salt solution, $L$-ascorbic acid solution, bathophenanthrolinedisulfonic acid disodium salt trihydrate, and azide-fluor 545 and stirring for $3 \mathrm{~h}$ at RT they labeled the exosomes' surface by the alkine-azide click chemistry (128). These experiments showed that the physicochemical properties of exosomes and their internalization by cells were not significantly affected by the click chemistry modification.

In a more recent study Smyth et al. investigated the biodistribution of the exosomes in comparison with liposomal formulations which are prepared with exosomal lipid extracts. They used fluorescent dye (1,1'-Dioctadecyl-3,3,3',3'Tetramethylindotricarbocyanine Iodide) (DIR) labeling or ${ }^{111} \mathrm{In}$ radiolabeling for in vivo biodistribution tracking and applied the formulations on different tumor bearing murine species (BALB/c, NU/J and NOD.CB17Prkdcscid/J). It has been observed that after intravenous administration neither exosomes nor liposomes are able to accumulate significantly in the tumors. The main sites of distribution were liver and spleen followed by kidneys and lungs. After intratumoral administration, however, analysis of the excised tumors revealed that exosomes stay associated with the tumors to a significantly greater degree than liposomes. So, it was concluded that unmodified exosomes are not useful as a tumor-specific delivery system for systemic administration, but may rather be preferable for intratumoral delivery (88).

The knowledge about development of targeted EV-based delivery systems is based on limited research papers. This strategy mainly involves usage of cell strains engineered with special plasmid vectors that encode fusion proteins. These fusion proteins consist of an EV transmembrane domain and a targeting domain, as in the case with luciferase labeling. The first study for targeted EV preparation and testing is that of Alvarez-Erviti and coworkers (76). They isolated dendritic cells from mice and genetically engineered them to express neurospecific $\mathrm{RVG}$ peptide fused to exosomal membrane protein; Lamp2b. Exosomes produced by these cells expressed RVG peptide on their surface which provided active targeting to neuronal cells in the brain. siRNA loaded to the neuronal-targeted RVG-exosomes shoved specific gene silencing activity on different parts of the brain and haven't induced nonspecific knockdown in the liver and other organs as was the case with naked siRNAs (76). Similarly, Tian et al. engineered mouse immature dendritic cells with iRGD-Lamp2b fusion protein (87). This ensured production of exosomes capable of targeting $\alpha \mathrm{v}$ integrinexpressing cancer cells. Compared to free drug, doxorubicin loaded to iRGD-targeted exosomes showed higher in vitro activity on MDA-MB-231 cancer cells. Besides, targeted exosomal doxorubicin exhibited higher in vivo antitumor activity in BALB/c nude mice. Significantly lower cardiac toxicity, a serious side effect of doxorubicin treatment, is observed with the targeted exosomal doxorubicin (87).

Ohno et al. engineered human embryonic kidney cells (HEK293) to express the transmembrane domain of platelet-derived growth factor receptor fused either to the epidermal growth factor receptor-binding peptide (GE11) or epidermal growth factor (EGF) (117). By this way they achieved targeting of miRNA-loaded EVs to EGFR overexpressing breast cancer cells (HCC70). In histological experiments researchers didn't find any organ damage in treated animals in vivo.

One challenge with the biodistribution and targeting studies of EVs is the incorporation of dyes, or other reporter molecules on the surface of EVs. Their presence on the membranes of EVs may lead to unpredicted reactions with the 
immune system subsequently leading to rapid elimination by the RES. Additionally it is not certain whether the signal observed is originating from the EV-associated dye, or from free dye molecules (124). At cellular level, although the dye appears localized in a given body region, it is not known to what extent it internalizes in the cytoplasm of individual cells in this region. Therefore, both the effect of the labeling technique on the biodistribution of EVs, and the internalization property of the reporter molecules at cellular level should be investigated in more detail.

From the research conducted on biodistribution of EVs, it appears that following in vivo administration unmodified EVs tend to localize mainly in the reticuloendothelial system (RES). This, in fact, may not only be a result of the possible immune reactions with the labeling molecules, but also due to the fact that the majority of EVs used in these studies are obtained from the culture medium of commercially available or previously established cell lines. In this instance the EVs are not originating from the animals they are going to be administered to. So, it is likely that these EVs could carry antigenic proteins on their surface, and thus, are recognized by the RES of the animals. As to a recent report it was demonstrated that the biodistribution of EVs is dependent on the source of producer cells, the route of administration, and the presence of targeting ligands on the surface of EVs (124). Good examples about the difference between the localization of exosomes in syngeneic and allogeneic animals are also provided $(76,124,129)$. Although it is concluded that there is no great difference between the biodistribution of EVs from individuals with distinct genetics, it appears that allogeneic and heterologous exosomes are more rapidly and extensively eliminated by the RES. Yet there are no real studies conducted with analogous EVs. It will be beneficial to conduct more studies that comparatively investigate the biodistribution pattern of analogous, syngeneic, allogeneic, and heterologous EVs in experimental animal models to determine if analogous EVs provide more satisfactory results such as escaping the RES and the immune system. The real question, what would be the possible fate of autologous (self) exosomes after intravenous administration remains unanswered. Table 4 summarizes recent biodistribution and targeting strategies on EV drug delivery. The table also provides a comparisaon of the sources of EV-producer cells and the experimental animal model used.
On the other hand, as the readily isolated and characterized cell lines provide the chance of straightforward applications, the establishment of primary cell culture from living animals in order to produce EVs with analogous character can be quite time-consuming and require special conditions like aseptic working area.

Another important issue which may concern not only the targeting ability, but also the labeling of EVs was pointed to be the degradation of targeting molecules on the surface of EVs during biogenesis which has recently been put on focus by Hung and Leonard (130). As transfection of producer cell lines appears the most relevant way of providing reporter/targeting ability to exosomes, this condition represents a challenge to overcome. It was shown that glycosylation is able to protect degradation of fusion proteins on EVs' surface and enhances the targeting potential (130).

While yet much research is needed to prove if there is a real benefit of autologous and syngeneic EVs over allogeneic ones in respect to their biodistribution and targeting ability, vesicles derived from prokaryotes, namely; bacterial outer membrane vesicles (OMVs) are also tested as targeted drug delivery vehicles for cancer therapy (119). Researchers used Escherichia coli strain with reduced endotoxicity to human cells and engineered the strain to express HER2 (human epidermal growth factor receptor-2) on the outer cell membrane which are later localized on released OMVs. Intravenous injection of these HER2 targeted OMVs resulted in targeted gene silencing and induced significant regression of tumor weight in a BALB/c nude mice xenografted with HER2 overexpressing HCC-1954 cells (119). No evidence for non-specific side effects was reported with OMVs in vivo.

\section{CONCLUSIONS}

The ability of EVs to incorporate intracellular substances and to transfer them efficiently to other cells, either endocrinally or paracrinally inspired scientists to introduce them in the field of drug and gene delivery. The advantage of EVs as drug delivery systems is mainly hidden in their feature to be of eobiotic origin, which means that they are composed of the same constituents of the organism to which they are going to be administered. They can be produced by virtually any cell type. Collecting cells from patients themselves and using these cells for production of self-derived nanosized vesicles for therapeutic molecule delivery could provide highly 
biocompatible and minimally toxic delivery nanovehicles.

Table 4. Summary of labeling methods and targeting strategies with extracellular vesicles.

\begin{tabular}{|c|c|c|c|c|c|}
\hline Reference & EV source & Cell line origin & $\begin{array}{l}\text { Administered } \\
\text { organism }\end{array}$ & $\begin{array}{l}\text { Distribution tracking / } \\
\text { visualization method }\end{array}$ & $\begin{array}{l}\text { Targeting } \\
\text { ligand }\end{array}$ \\
\hline (84) & EL-C cells & $\begin{array}{l}\text { C57BL/6n } \\
\text { mouse } \\
\text { lymphoma }\end{array}$ & $\begin{array}{l}\mathrm{C} 57 \mathrm{BL} / 6 \mathrm{j} \\
\text { mice }\end{array}$ & $\begin{array}{l}\text { IRDye-800CW fluorescent } \\
\text { dye }\end{array}$ & - \\
\hline \multirow[t]{2}{*}{ (88) } & 4T1 cells & $\begin{array}{l}\mathrm{BALB} / \mathrm{c} \text { fC3H } \\
\text { mouse } \\
\text { mammary gland } \\
\text { tumor }\end{array}$ & $\begin{array}{l}\text { BALB/c mice, } \\
\text { NOD.CB17- } \\
\text { Prkdcscid/j mice, } \\
\text { Nude mice }\end{array}$ & DiR fluorescent dye & - \\
\hline & $\begin{array}{l}\text { PC3 and MCF7 } \\
\text { cell lines }\end{array}$ & $\begin{array}{l}\text { Human prostate } \\
\text { and breast } \\
\text { adenocarcinoma }\end{array}$ & Nude mice & ${ }^{111}$ In radiolabeling & - \\
\hline (91) & Raw 264.7 cells & $\begin{array}{l}\mathrm{BALB} / \mathrm{c} \text { mouse } \\
\text { macrophages }\end{array}$ & C57BL/6 mice & Dil fluorescent dye & - \\
\hline (123) & $\begin{array}{l}\text { Mesenchymal } \\
\text { stem cells }\end{array}$ & Human & CD1 nude mice & DiD fluorescent dye & - \\
\hline \multirow{6}{*}{ (124) } & Dendritic cells & $\begin{array}{l}\text { C57BL/ } 6 \text { mouse } \\
\text { bone marrow }\end{array}$ & NMRI mice & DiR fluorescent dye & RVG peptide \\
\hline & $\begin{array}{l}\text { Mesenchymal } \\
\text { stem cells }\end{array}$ & $\begin{array}{l}\text { Human bone } \\
\text { marrow aspirates }\end{array}$ & NMRI mice & DiR fluorescent dye & - \\
\hline & HEK293T cells & $\begin{array}{l}\text { Human } \\
\text { embryonic } \\
\text { kidney }\end{array}$ & $\begin{array}{l}\mathrm{NMRI} \text { or } \\
\mathrm{C} 57 \mathrm{BL} / 6 \text { mice }\end{array}$ & $\begin{array}{l}\text { DiR fluorescent dye } \\
\text { or EGFP }\end{array}$ & - \\
\hline & $\mathrm{C} 2 \mathrm{C} 12$ cells & $\begin{array}{l}\mathrm{C} 3 \mathrm{H} \text { mouse } \\
\text { muscle tissue }\end{array}$ & NMRI mice & DiR fluorescent dye & - \\
\hline & B16-F10 cells & $\begin{array}{l}\mathrm{C} 57 \mathrm{BL} / 6 \mathrm{j} \\
\text { mouse } \\
\text { melanoma }\end{array}$ & NMRI mice & DiR fluorescent dye & - \\
\hline & OLN-93 cells & $\begin{array}{l}\text { Rat } \\
\text { oligodendrocytes }\end{array}$ & NMRI mice & DiR fluorescent dye & - \\
\hline (125) & B16BL6 cells & $\begin{array}{l}\text { C57BL/6 mouse } \\
\text { melanona }\end{array}$ & $\mathrm{BALB} / \mathrm{c}$ & ${ }^{125} \mathrm{I}$ radiolabeling & - \\
\hline (126) & B16BL6 cells & $\begin{array}{l}\text { C57BL/6 mouse } \\
\text { melanoma }\end{array}$ & $\begin{array}{l}\mathrm{C} 57 \mathrm{BL} / 6 \text { and } \\
\mathrm{BALB} / \mathrm{c} \text { mice }\end{array}$ & $\begin{array}{ll}\text { Gaussia luciferase } & \text { or } \\
\text { PKH26 } & \end{array}$ & - \\
\hline (127) & HEK293T cells & $\begin{array}{l}\text { Human } \\
\text { embryonic } \\
\text { kidney }\end{array}$ & Nude mice & $\begin{array}{l}\text { Gaussia luciferase or } \\
\text { biotin-fused } \\
\text { luciferase }\end{array}$ & \\
\hline (128) & 4T1 cells & $\begin{array}{l}\mathrm{BALB} / \mathrm{c} \text { fC3H } \\
\text { mouse } \\
\text { mammary gland } \\
\text { tumor }\end{array}$ & in vitro tested & Azide-Fluor 545 & - \\
\hline (76) & Dendritic cells & $\begin{array}{l}\text { C57BL/6 mouse } \\
\text { bone marrow }\end{array}$ & $\begin{array}{l}\text { C57BL/6 } \\
\mathrm{BALB} / \mathrm{c}\end{array}$ & na & $\begin{array}{lr}\text { RVG } & \text { peptide } \\
\text { or } & \text { MSP } \\
\text { peptide } & \end{array}$ \\
\hline (87) & Dendritic cells & Immature mouse & $\begin{array}{l}\mathrm{BALB} / \mathrm{c} \text { nude } \\
\text { mice }\end{array}$ & DiR fluorescent dye & iRGD peptide \\
\hline (117) & HEK239 cells & $\begin{array}{l}\text { Human } \\
\text { embryonic } \\
\text { kidney }\end{array}$ & RAG $2^{-/-}$mice & DiR fluorescent dye & GE11 peptide \\
\hline (119) & $\begin{array}{l}\text { msbB mutant } \\
\text { W3110 E. coli }\end{array}$ & $\begin{array}{l}\text { K12-derived } E \text {. } \\
\text { coli strain }\end{array}$ & $\begin{array}{l}\mathrm{BALB} / \mathrm{c} \text { nude } \\
\text { mice }\end{array}$ & Cy5.5-labeled siRNA & affi $_{\text {HER2 }}$ peptide \\
\hline
\end{tabular}

May be the most important hallmark of these selfderived, nanosized vesicles is their tremendous convenience for developing personalized nanomedicines. 
As the field of extracellular vesicle research continuously produces advanced knowledge for their role in biological pathways, cell-cell communications, pathogenesis, disease progression, biomarker development etc., much work is yet to be performed to further understand their potential for drug delivery purposes. Firstly, although there is a substantial amount of knowledge concerning the biogenesis of EVs, exact mechanisms of their formation and release still remain to be clarified. While the postisolation loading can be investigated in a way similar to the liposome research, little is known about the basic phenomena lying behind drug, protein or genetic material sorting into EVs during their biogenesis.

Secondly, compared to other conventional nanoparticle types, the difficulties opposing the development of a reproducible and calibrated method of EV production appear to be the greatest technical challenge for EVs in the field of therapeutics delivery. The producer cells, cell culture conditions, isolation and characterization techniques all need to be improved in order to obtain a reproducible and calibrated method of production of EVs with GMP compliance. They also cannot be subjected to procedures like homogenization and particle size reduction.

Thirdly, together with the assumptions for their great compatibility as self-derived vesicles, the safety concept of extracellular vesicles should also be clarified in more detail. For example some reports imply that possible future use of EVs as drug delivery vehicles should be accompanied by considerations of kidney health in order to avoid unwanted accumulation of drugs and consequent side effects. Once their safety aspect is clarified, these tiny self-derived nano-sized vesicles would boost the efficacy of many small molecule drugs and biopharmaceuticals.

In conclusion, drug and gene delivery through biologically derived nanovesicles is becoming more and more attractive subject for the medicine. According to the literature reports extracellular vesicles are expected to be less toxic, and more compatible with the host immune system than liposomes and other nanoparticles with synthetic origin. Furthermore, the great opportunity to isolate specific cells from a host organism and use them for production of extracellular vesicles with targeting moieties will pave the way for development of personalized nanomedicines of the future.

\section{ACKNOWLEDGEMENTS}

We thank Prof. Dr. Gülten Kantarcı and Prof. Dr. Zeki Topçu from Ege University, and Dr. Okay Saydam from Medical University of Vienna for the critical reading of the manuscript.

\section{REFERENCES}

1. Basavaraj S, Betageri G V. Can formulation and drug delivery reduce attrition during drug discovery and development-review of feasibility, benefits and challenges. Acta Pharm Sin B. 2014;4(1):3-17.

2. Hoffman AS. The origins and evolution of "controlled" drug delivery systems. J Control Release. 2008;132(3):153-63.

3. Wilczewska AZ, Niemirowicz K, Markiewicz $\mathrm{KH}$, Car H. Nanoparticles as drug delivery systems. Pharmacol Rep. 2012;64(5):1020-37.

4. Merisko-Liversidge EM, Liversidge GG. Drug nanoparticles: formulating poorly water-soluble compounds. Toxicol Pathol. 2008;36:43-8.

5. Nazar MF, Khan AM, Shah SS. Microemulsion system with improved loading of piroxicam: a study of microstructure. AAPS PharmSciTech. 2009;10(4):1286-94.

6. Wei T, Liu J, Ma H, Cheng Q, Huang Y, Zhao J, et al. Functionalized nanoscale micelles improve drug delivery for cancer therapy in vitro and in vivo. Nano Lett. 2013;13(6):2528-34.

7. Dang Y-J, Zhu C-Y. Oral bioavailability of cantharidin-loaded solid lipid nanoparticles. Chin Med. 2013;8(1):1.

8. Abd-Allah FI, Dawaba HM, Ahmed AM. Development of a microemulsion-based formulation to improve the availability of poorly water-soluble drug. Drug Discov Ther. 2010;4(4):257-66.

9. Jesson $\mathrm{G}$, Brisander $\mathrm{M}$, Andersson $\mathrm{P}$, Demirbüker M, Derand H, Lennernäs $\mathrm{H}$, et al. Carbon dioxide-mediated generation of hybrid nanoparticles for improved bioavailability of protein kinase inhibitors. Pharm Res. 2014;31(3):694-705.

10. Dwivedi P, Khatik R, Khandelwal K, Taneja I, Raju KSR, Wahajuddin, et al. Pharmacokinetics study of arteether loaded solid lipid nanoparticles: an improved oral bioavailability in rats. Int J Pharm. 2014;466(1-2):321-7.

11. Singh G, Pai RS. Optimized PLGA nanoparticle platform for orally dosed trans-resveratrol with enhanced bioavailability potential. Expert Opin Drug Deliv. 2014;11(5):647-59.

12. Joshi G, Kumar A, Sawant K. Enhanced bioavailability and intestinal uptake of Gemcitabine $\mathrm{HCl}$ loaded PLGA nanoparticles after oral delivery. Eur J Pharm Sci. 2014;60:80-9.

13. Gaur PK, Mishra S, Bajpai M, Mishra A. Enhanced oral bioavailability of efavirenz by solid lipid nanoparticles: in vitro drug release and pharmacokinetics studies. Biomed Res Int. 2014;2014:363404. 
14. Kotmakchiev M, Kantarcı G, Çetintas VB, Ertan G. Cytotoxicity of a Novel Oil / Water Microemulsion System Loaded with Mitomycin-C in In Vitro Lung Cancer Models. Drug Dev Res. 2012;195:185-95.

15. Kiziltepe T, Ashley JD, Stefanick JF, Qi YM, Alves NJ, Handlogten MW, et al. Rationally engineered nanoparticles target multiple myeloma cells, overcome cell-adhesionmediated drug resistance, and show enhanced efficacy in vivo. Blood Cancer J. 2012;2(4):e64.

16. Azzi J, Tang L, Moore R, Tong R, El Haddad N, Akiyoshi T, et al. Polylactide-cyclosporin A nanoparticles for targeted immunosuppression. FASEB J. 2010;24(10):3927-38.

17. Casa DM, Moraes Carraro TCM, De Camargo LEA, Dalmolin LF, Khalil NM, Mainardes RM. Poly(L-lactide) Nanoparticles Reduce Amphotericin B Cytotoxicity and Maintain Its In VitroAntifungal Activity. J Nanosci Nanotechnol. American Scientific Publishers; 2015;15(1):848-54.

18. Amaral AC, Bocca AL, Ribeiro AM, Nunes J, Peixoto DLG, Simioni AR, et al. Amphotericin $\mathrm{B}$ in poly(lactic-co-glycolic acid) (PLGA) and dimercaptosuccinic acid (DMSA) nanoparticles against paracoccidioidomycosis. J Antimicrob Chemother 2009;63(3):526-33.

19. Chen JP, Yang PC, Ma YH, Tu SJ, Lu YJ. Targeted delivery of tissue plasminogen activator by binding to silica-coated magnetic nanoparticle. Int J Nanomedicine. 2012;7:513749.

20. Oh B, Han J, Choi E, Tan X, Lee M. Peptide Micelle-Mediated Delivery of Tissue-Specific Suicide Gene and Combined Therapy with Avastin in a Glioblastoma Model. J Pharm Sci. 2015;104(4):1461-9.

21. Leung AKK, Tam YYC, Cullis PR. Lipid nanoparticles for short interfering RNA delivery. Adv Genet. 2014;88:71-110.

22. Sun Z, Song X, Li X, Su T, Qi S, Qiao R, et al. In vivo multimodality imaging of miRNA-16 iron nanoparticle reversing drug resistance to chemotherapy in a mouse gastric cancer model. Nanoscale. 2014;6(23):14343-53.

23. Han J, Cai J, Borjihan W, Ganbold T, Rana TM, Baigude H. Preparation of novel curdlan nanoparticles for intracellular siRNA delivery. Carbohydr Polym. 2015;117:324-30.

24. Afonin KA, Viard M, Kagiampakis I, Case CL, Dobrovolskaia MA, Hofmann J, et al. Triggering of RNA Interference with RNARNA, RNA-DNA, and DNA-RNA Nanoparticles. ACS Nano. 2014;9(1):251-9.

25. Liu J, Zhang B, Luo Z, Ding X, Li J, Dai L, et al. Enzyme responsive mesoporous silica nanoparticles for targeted tumor therapy in vitro and in vivo. Nanoscale. 2015;7(8):3614-26.

26. Mansourpour M, Mahjub R, Amini M, Ostad SN, Shamsa ES, Rafiee-Tehrani $M$, et al. Development of Acid-Resistant
Alginate/Trimethyl Chitosan Nanoparticles Containing Cationic $\beta$-Cyclodextrin Polymers for Insulin Oral Delivery. AAPS PharmSciTech. 2015;16(4):952-62.

27. Sivasubramanian M, Lee J-Y, Kim KJ, Saravanakumar G, Kang YM, Park JH. Cyclodextrin-based nanocomplexes for sustained delivery of human growth hormone. J Nanosci Nanotechnol. 2013;13(11):7306-11.

28. Zolnik BS, González-Fernández A, Sadrieh N, Dobrovolskaia MA. Nanoparticles and the immune system. Endocrinology. 2010;151(2):458-65.

29. Ray $\mathrm{PC}, \mathrm{Yu} \mathrm{H}, \mathrm{Fu}$ PP. Toxicity and environmental risks of nanomaterials: challenges and future needs. J Environ Sci Health C Environ Carcinog Ecotoxicol Rev. 2009;27(1):1-35.

30. Dhawan A, Sharma V, Parmar D. Nanomaterials: A challenge for toxicologists. Nanotoxicology. 2009;3(1):1-9.

31. Dhawan A, Sharma V. Toxicity assessment of nanomaterials: methods and challenges. Anal Bioanal Chem. 2010;398(2):589-605.

32. Shukla S, Jadaun A, Arora V, Sinha RK, Biyani $\mathrm{N}$, Jain VK. In vitro toxicity assessment of chitosan oligosaccharide coated iron oxide nanoparticles. Toxicol Reports. 2015;2:27-39.

33. Chen WC, May JP, Li S-D. Immune responses of therapeutic lipid nanoparticles. Nanotechnol Rev. 2013;2(2):201-13.

34. Kumar V, Qin J, Jiang Y, Duncan RG, Brigham B, Fishman S, et al. Shielding of Lipid Nanoparticles for siRNA Delivery: Impact on Physicochemical Properties, Cytokine Induction, and Efficacy. Mol Ther Nucleic Acids. 2014;3:e210.

35. Chan VSW. Nanomedicine: An unresolved regulatory issue. Regul Toxicol Pharmacol. 2006;46:218-24.

36. Scott-Fordsmand JJ, Pozzi-Mucelli S, Tran L, Aschberger K, Sabella S, Vogel U, et al. A unified framework for nanosafety is needed. Nano Today. 2014;9(5):546-9.

37. El-Ansary a, Al-Daihan S. On the toxicity of therapeutically used nanoparticles: an overview. J Toxicol. 2009;2009:754810.

38. Mogharabi M, Abdollahi M, Faramarzi MA. Toxicity of nanomaterials; an undermined issue. DARU J Pharm Sci. 2014;22(1):59.

39. HALFORD B. NANOTOXICITY. In vivo study of fullerenes contradicts in vitro data. Chem Eng News. 2007;85(30):11a.

40. Hartung T. Look back in anger - what clinical studies tell us about preclinical work. ALTEX. 2013;30(3):275-91.

41. Xue HY, Liu S, Wong HL. Nanotoxicity: a key obstacle to clinical translation of siRNA-based nanomedicine. Nanomedicine (Lond). 2014;9(2):295-312.

42. Gangoda L, Boukouris S, Liem M, Kalra H, Mathivanan S. Extracellular vesicles including 
exosomes are mediators of signal transduction: Are they protective or pathogenic? Proteomics. 2015;15(2-3):260-71.

43. Johnstone RM, Adam M, Hammond JR, Orr L, Turbide C. Vesicle formation during reticulocyte maturation. Association of plasma membrane activities with released vesicles (exosomes). J Biol Chem. 1987;262(19):941220.

44. Sun D, Zhuang X, Zhang S, Deng Z-B, Grizzle $\mathrm{W}$, Miller D, et al. Exosomes are endogenous nanoparticles that can deliver biological information between cells. Adv Drug Deliv Rev. 2013;65(3):342-7.

45. Van Doormaal FF, Kleinjan A, Di Nisio M, Büller HR, Nieuwland R. Cell-derived microvesicles and cancer. Neth J Med. 2009;67(7):266-73.

46. D'Souza-Schorey C, Clancy JW. Tumor-derived microvesicles: shedding light on novel microenvironment modulators and prospective cancer biomarkers. Genes Dev. 2012;26(12):1287-99.

47. Henry CM, Hollville E, Martin SJ. Measuring apoptosis by microscopy and flow cytometry. Methods. 2013;61(2):90-7.

48. Akers JC, Gonda D, Kim R, Carter BS, Chen CC. Biogenesis of extracellular vesicles $(\mathrm{EV})$ : exosomes, microvesicles, retrovirus-like vesicles, and apoptotic bodies. J Neurooncol. 2013];113(1):1-11.

49. Osteikoetxea X, Balogh A, Szabó-Taylor K, Németh A, Szabó TG, Pálóczi K, et al. Improved Characterization of EV Preparations Based on Protein to Lipid Ratio and Lipid Properties. PLoS One. 2015;10(3):e0121184.

50. Fan G-C. Hypoxic exosomes promote angiogenesis. Blood. 2014;124(25):3669-70.

51. Wang G-J, Liu Y, Qin A, Shah S V, Deng Z, Xiang $\mathrm{X}$, et al. Thymus exosomes-like particles induce regulatory $\mathrm{T}$ cells. $\mathrm{J}$ Immunol. 2008;181(8):5242-8.

52. Baragaño Raneros A, Suarez-Álvarez B, LópezLarrea C. Secretory pathways generating immunosuppressive NKG2D ligands: New targets for therapeutic intervention. Oncoimmunology. 2014;3:e28497.

53. Corrado C, Raimondo S, Saieva L, Flugy AM, De Leo G, Alessandro R. Exosome-mediated crosstalk between chronic myelogenous leukemia cells and human bone marrow stromal cells triggers an interleukin 8-dependent survival of leukemia cells. Cancer Lett. 2014 348(1-2):71-6.

54. Baixauli F, López-Otín C, Mittelbrunn M. Exosomes and autophagy: coordinated mechanisms for the maintenance of cellular fitness. Front Immunol. 2014;5:403.

55. Ailawadi $\mathrm{S}$, Wang $\mathrm{X}$, Gu H, Fan G-C. Pathologic function and therapeutic potential of exosomes in cardiovascular disease. Biochim Biophys Acta. 2014;1852(1):1-11.
56. Wang J, Hendrix A, Hernot S, Lemaire M, De Bruyne E, Van Valckenborgh E, et al. Bone marrow stromal cell-derived exosomes as communicators in drug resistance in multiple myeloma cells. Blood. 2014;124(4):555-66.

57. Crunkhorn S. Cancer: Cancer exosomes promote tumorigenesis. Nat Rev Drug Discov. 2014;14(1):16.

58. Jovic M, Sharma M, Rahajeng J, Caplan S. The early endosome: a busy sorting station for proteins at the crossroads. Histol Histopathol. 2010;25(1):99-112.

59. Andreu Z, Yáñez-Mó M. Tetraspanins in extracellular vesicle formation and function. Front Immunol. 2014;5:442.

60. Henne WM, Buchkovich NJ, Emr SD. The ESCRT pathway. Dev Cell. 2011;21(1):77-91.

61. Babst M. MVB vesicle formation: ESCRTdependent, ESCRT-independent and everything in between. Curr Opin Cell Biol. 2011;23(4):452-7.

62. Teo H, Perisic O, González B, Williams RL. ESCRT-II, an endosome-associated complex required for protein sorting: crystal structure and interactions with ESCRT-III and membranes. Dev Cell. 2004;7(4):559-69.

63. Hurley JH, Hanson PI. Membrane budding and scission by the ESCRT machinery: it's all in the neck. Nat Rev Mol Cell Biol. 2010;11(8):55666.

64. Sadallah S, Eken C, Schifferli JA. Ectosomes as modulators of inflammation and immunity. Clin Exp Immunol. 2011;163(1):26-32.

65. Hugel B, Martínez MC, Kunzelmann C, Freyssinet J-M. Membrane microparticles: two sides of the coin. Physiology (Bethesda).;20:227.

66. Raposo G, Stoorvogel W. Extracellular vesicles: exosomes, microvesicles, and friends. J Cell Biol. 2013;200(4):373-83.

67. Chang H-I, Yeh M-K. Clinical development of liposome-based drugs: formulation, characterization, and therapeutic efficacy. Int $\mathrm{J}$ Nanomedicine. 2012;7:49-60.

68. Van Dommelen SM, Vader P, Lakhal S, Kooijmans S a a, van Solinge WW, Wood MJ a, et al. Microvesicles and exosomes: opportunities for cell-derived membrane vesicles in drug delivery. J Control Release. 2012;161(2):63544.

69. Lai RC, Yeo RWY, Tan KH, Lim SK. Exosomes for drug delivery - a novel application for the mesenchymal stem cell. Biotechnol Adv. 2013;31(5):543-51.

70. El Andaloussi S, Lakhal S, Mäger I, Wood MJ a. Exosomes for targeted siRNA delivery across biological barriers. Adv Drug Deliv Rev. 2013 65(3):391-7.

71. Kosaka N, Takeshita F, Yoshioka Y, Hagiwara K, Katsuda T, Ono M, et al. Exosomal tumorsuppressive microRNAs as novel cancer therapy: "exocure" is another choice for cancer 
treatment. Adv Drug Deliv Rev. 2013;65(3):376-82.

72. Koppers-Lalic D, Hogenboom MM, Middeldorp JM, Pegtel DM. Virus-modified exosomes for targeted RNA delivery; a new approach in nanomedicine. Adv Drug Deliv Rev. 2013;65(3):348-56.

73. Van den Boorn JG, Dassler J, Coch C, Schlee M, Hartmann G. Exosomes as nucleic acid nanocarriers. Adv Drug Deliv Rev. 2013 Mar;65(3):331-5.

74. Johnsen KB, Gudbergsson JM, Skov MN, Pilgaard L, Moos T, Duroux M. A comprehensive overview of exosomes as drug delivery vehicles - Endogenous nanocarriers for targeted cancer therapy. Biochim Biophys Acta. 2014;1846(1):75-87.

75. Van der Meel R, Fens $\mathrm{MH}$ a M, Vader P, van Solinge WW, Eniola-Adefeso O, Schiffelers RM. Extracellular vesicles as drug delivery systems: Lessons from the liposome field. J Control Release. 2014;195:72-85.

76. Alvarez-Erviti L, Seow Y, Yin H, Betts C, Lakhal S, Wood MJA. Delivery of siRNA to the mouse brain by systemic injection of targeted exosomes. Nat Biotechnol. 2011;29(4):341-5.

77. Balazs D a, Godbey W. Liposomes for use in gene delivery. J Drug Deliv. 2011;2011:326497.

78. Shim G, Kim M-G, Park JY, Oh Y-K. Application of cationic liposomes for delivery of nucleic acids. Asian J Pharm Sci. 2013;8(2):72-80.

79. McCaskill J, Singhania R, Burgess M, Allavena $\mathrm{R}, \mathrm{Wu} \mathrm{S}$, Blumenthal $\mathrm{A}$, et al. Efficient Biodistribution and Gene Silencing in the Lung epithelium via Intravenous Liposomal Delivery of siRNA. Mol Ther Nucleic Acids. 2013;2:e96.

80. Kikuchi H, Suzuki N, Ebihara K, Morita H, Ishii Y, Kikuchi A, et al. Gene delivery using liposome technology. J Control Release. 1999;62(1-2):269-77.

81. Smyth Templeton N. Liposomal delivery of nucleic acids in vivo. DNA Cell Biol. 2002;21(12):857-67.

82. Ewert KK, Ahmad A, Bouxsein NF, Evans HM, Safinya CR. Non-viral gene delivery with cationic liposome-DNA complexes. Methods Mol Biol. 2008;433:159-75.

83. Vader P, Kooijmans S a a, Stremersch S, Raemdonck K. New considerations in the preparation of nucleic acid-loaded extracellular vesicles. Ther Deliv. 2014;5(2):105-7.

84. Sun D, Zhuang X, Xiang X, Liu Y, Zhang S, Liu $C$, et al. A novel nanoparticle drug delivery system: the anti-inflammatory activity of curcumin is enhanced when encapsulated in exosomes. Mol Ther. 2010;18(9):1606-14.

85. Zhuang X, Xiang X, Grizzle W, Sun D, Zhang $\mathrm{S}$, Axtell RC, et al. Treatment of brain inflammatory diseases by delivering exosome encapsulated anti-inflammatory drugs from the nasal region to the brain. Mol Ther. 2011;19(10):1769-79.

86. Jang SC, Kim OY, Yoon CM, Choi D, Roh T, Park J, et al. Bioinspired Exosome-Mimetic Nanovesicles for Targeted Delivery of Chemotherapeutics to Malignant Tumors. ACS Nano. 2013;7(9):7698-710.

87. Tian Y, Li S, Song J, Ji T, Zhu M, Anderson GJ, et al. A doxorubicin delivery platform using engineered natural membrane vesicle exosomes for targeted tumor therapy. Biomaterials. 2014;35(7):2383-90.

88. Smyth T, Kullberg M, Malik N, Smith-Jones P, Graner MW, Anchordoquy TJ. Biodistribution and Delivery Efficiency of Unmodified TumorDerived Exosomes. J Control Release. 2015;199:145-55.

89. Yang T, Martin P, Fogarty B, Brown A, Schurman K, Phipps R, et al. Exosome Delivered Anticancer Drugs Across the BloodBrain Barrier for Brain Cancer Therapy in Danio Rerio. Pharm Res. 2015;32(6):2003-14.

90. Hood JL, Scott MJ, Wickline SA. Maximizing exosome colloidal stability following electroporation. Anal Biochem. 2014;448:41-9.

91. Haney MJ, Klyachko NL, Zhao Y, Gupta R, Plotnikova EG, He Z, et al. Exosomes as drug delivery vehicles for Parkinson's disease therapy. J Control Release 2015;207:18-30.

92. Fuhrmann G, Serio A, Mazo M, Nair R, Stevens MM. Active loading into extracellular vesicles significantly improves the cellular uptake and photodynamic effect of porphyrins. J Control Release. 2014;205:35-44.

93. Safaei R, Larson BJ, Cheng TC, Gibson M a, Otani S, Naerdemann W, et al. Abnormal lysosomal trafficking and enhanced exosomal export of cisplatin in drug-resistant human ovarian carcinoma cells. Mol Cancer Ther. 2005;4(10):1595-604.

94. Ouar Z, Bens M, Vignes C, Paulais M, Pringel $\mathrm{C}$, Fleury $\mathrm{J}$, et al. Inhibitors of vacuolar $\mathrm{H}+-$ ATPase impair the preferential accumulation of daunomycin in lysosomes and reverse the resistance to anthracyclines in drug-resistant renal epithelial cells. Biochem J. 2003;370:18593.

95. Hurwitz S, Terashima M, Mizunuma N, Christopher S. Vesicular anthracycline accumulation in doxorubicin-selected U-937 cells: participation of lysosomes. Blood. 1997 ;89(10):3745-55.

96. Yamagishi T, Sahni S, Sharp DM, Arvind A, Jansson PJ, Richardson DR. P-glycoprotein mediates drug resistance via a novel mechanism involving lysosomal sequestration. J Biol Chem. 2013;288(44):31761-71.

97. Pascucci L, Coccè V, Bonomi A, Ami D, Ceccarelli P, Ciusani E, et al. Paclitaxel is incorporated by mesenchymal stromal cells and released in exosomes that inhibit in vitro tumor 
growth: a new approach for drug delivery. J Control Release. 2014;192:262-70.

98. Dominska M, Dykxhoorn DM. Breaking down the barriers: siRNA delivery and endosome escape. J Cell Sci. 2010;123(Pt 8):1183-9.

99. Zhu L, Mahato RI. Lipid and polymeric carriermediated nucleic acid delivery. Expert Opin Drug Deliv. 2010;7(10):1209-26.

100. Dizaj SM, Jafari S, Khosroushahi AY. A sight on the current nanoparticle-based gene delivery vectors. Nanoscale Res Lett. 2014;9(1):252.

101. Lotvall J, Valadi H. Cell to Cell Signalling via Exosomes Through esRNA. Cell Adh Migr. 2007;1(3):156-8.

102. Zhao L, Liu W, Xiao J, Cao B. The role of exosomes and "exosomal shuttle microRNA" in tumorigenesis and drug resistance. Cancer Lett. 2014;356(2):339-46.

103. Gajos-Michniewicz A, Duechler M, Czyz M. MiRNA in melanoma-derived exosomes. Cancer Lett. 2014;347(1):29-37.

104. Guduric-Fuchs J, O’Connor A, Camp B, O’Neill CL, Medina RJ, Simpson D a. Selective extracellular vesicle-mediated export of an overlapping set of microRNAs from multiple cell types. BMC Genomics. 2012;13(1):357.

105. Lässer C, Eldh M, Lötvall J. Isolation and characterization of RNA-containing exosomes. J Vis Exp. 2012;(59):e3037.

106. Gibbings DJ, Ciaudo C, Erhardt M, Voinnet O. Multivesicular bodies associate with components of miRNA effector complexes and modulate miRNA activity. Nat Cell Biol. 2009;11(9):1143-9.

107. Hagiwara K, Ochiya T, Kosaka N. A paradigm shift for extracellular vesicles as small RNA carriers: from cellular waste elimination to therapeutic applications. Drug Deliv Transl Res. 2014;4(1):31-7.

108. Momen-Heravi F, Bala S, Bukong T, Szabo G. Exosome-mediated delivery of functionally active miRNA-155 inhibitor to macrophages. Nanomedicine. 2014;10(7):1517-27.

109. Banizs AB, Huang T, Dryden K, Berr SS, Stone JR, Nakamoto RK, et al. In vitro evaluation of endothelial exosomes as carriers for small interfering ribonucleic acid delivery. Int $\mathrm{J}$ Nanomedicine. 2014;9:4223-30.

110. Shtam TA, Kovalev RA, Varfolomeeva EY, Makarov EM, Kil Y V, Filatov M V. Exosomes are natural carriers of exogenous siRNA to human cells in vitro. Cell Commun Signal. 2013;11:88.

111. Squadrito ML, Baer C, Burdet F, Maderna C, Gilfillan GD, Lyle R, et al. Endogenous RNAs Modulate MicroRNA Sorting to Exosomes and Transfer to Acceptor Cells. Cell Rep. 2014;1432-46.

112. Maguire CA, Balaj L, Sivaraman S, Crommentuijn MHW, Ericsson M, MinchevaNilsson L, et al. Microvesicle-associated AAV vector as a novel gene delivery system. Mol Ther. 2012;20(5):960-71.

113. Xin H, Li Y, Buller B, Katakowski M, Zhang Y, Wang $X$, et al. Exosome-mediated transfer of miR-133b from multipotent mesenchymal stromal cells to neural cells contributes to neurite outgrowth. Stem Cells. 2012;30(7):1556-64.

114. Bolukbasi MF, Mizrak A, Ozdener GB, Madlener S, Ströbel T, Erkan EP, et al. miR1289 and "Zipcode"-like Sequence Enrich mRNAs in Microvesicles. Mol Ther - Nucleic Acids. 2012;1:e10.

115. Akao $\mathrm{Y}$, Iio $\mathrm{A}$, Itoh $\mathrm{T}$, Noguchi $\mathrm{S}$, Itoh $\mathrm{Y}$, Ohtsuki Y, et al. Microvesicle-mediated RNA molecule delivery system using monocytes/macrophages. Mol Ther. 2011;19(2):395-9.

116. Munoz JL, Bliss SA, Greco SJ, Ramkissoon SH, Ligon KL, Rameshwar P. Delivery of Functional Anti-miR-9 by Mesenchymal Stem Cell-derived Exosomes to Glioblastoma Multiforme Cells Conferred Chemosensitivity. Mol Ther Nucleic Acids. 2013;2:e126.

117. Ohno S, Takanashi M, Sudo K, Ueda S, Ishikawa A, Matsuyama N, et al. Systemically Injected Exosomes Targeted to EGFR Deliver Antitumor MicroRNA to Breast Cancer Cells. Mol Ther. 2013;21(1):185-91.

118. Zhang Y, Li L, Yu J, Zhu D, Zhang Y, Li X, et al. Microvesicle-mediated delivery of transforming growth factor $\beta 1$ siRNA for the suppression of tumor growth in mice. Biomaterials. 2014;35(14):4390-400.

119. Gujrati V, Kim S, Kim S-H, Min JJ, Choy HE, Kim SC, et al. Bioengineered bacterial outer membrane vesicles as cell-specific drugdelivery vehicles for cancer therapy. ACS Nano. 2014;8(2):1525-37.

120. Daya S, Berns KI. Gene therapy using adenoassociated virus vectors. Clin Microbiol Rev. 2008;21(4):583-93.

121. Ge Q, Zhou Y, Lu J, Bai Y, Xie X, Lu Z. MiRNA in plasma exosome is stable under different storage conditions. Molecules. 2014;19:1568-75.

122. Cheng L, Sharples R a, Scicluna BJ, Hill AF. Exosomes provide a protective and enriched source of miRNA for biomarker profiling compared to intracellular and cell-free blood. J Extracell Vesicles. 2014;3:1-14.

123. Grange C, Tapparo M, Bruno S, Chatterjee D, Quesenberry PJ, Tetta C, et al. Biodistribution of mesenchymal stem cell-derived extracellular vesicles in a model of acute kidney injury monitored by optical imaging. Int $\mathrm{J}$ Mol Med. 2014;33(5):1055-63.

124. Wiklander OPB, Nordin JZ, O'Loughlin A, Gustafsson Y, Corso G, Mäger I, et al. Extracellular vesicle in vivo biodistribution is determined by cell source, route of 
administration and targeting. $\mathrm{J}$ Extracell Vesicles. 2015;4:26316.

125. Morishita M, Takahashi Y, Nishikawa M, Sano K, Kato K, Yamashita T, et al. Quantitative Analysis of Tissue Distribution of the B16BL6Derived Exosomes Using a StreptavidinLactadherin Fusion Protein and Iodine-125Labeled Biotin Derivative After Intravenous Injection in Mice. J Pharm Sci. 2015;104(2):705-13.

126. Takahashi $Y$, Nishikawa $M$, Shinotsuka $H$, Matsui Y, Ohara S, Imai T, et al. Visualization and in vivo tracking of the exosomes of murine melanoma B16-BL6 cells in mice after intravenous injection. $\mathrm{J}$ Biotechnol. 2013;165(2):77-84.

127. Lai CP, Mardini O, Ericsson M, Prabhakar S, Maguire CA, Chen JW, et al. Dynamic biodistribution of extracellular vesicles in vivo using a multimodal imaging reporter. ACS Nano. 2014;8(1):483-94.

128. Smyth T, Petrova K, Payton NM, Persaud I, Redzic JS, Graner MW, et al. Surface functionalization of exosomes using click chemistry. Bioconjug Chem. 2014;25(10):177784.

129. Beauvillain C, Ruiz S, Guiton R, Bout D, Dimier-Poisson I. A vaccine based on exosomes secreted by a dendritic cell line confers protection against $\mathrm{T}$. gondii infection in syngeneic and allogeneic mice. Microbes Infect. 2007;9(14-15):1614-22.

130. Hung ME, Leonard JN. Stabilization of Exosome-targeting Peptides via Engineered Glycosylation. J Biol Chem. 2015;290(13):8166-72. 